\title{
THE METHOD OF CHOICE FOR REPORTING COMPREHENSIVE INCOME
}

\author{
Kendra Huff, Natalya (Natasha) Delcoure \\ Texas A\&M University - Kingsville
}

\begin{abstract}
Globalization of financial markets and exponential growth of cross-listing of foreign companies on stock exchanges in other countries throughout the world call for a need of a single global accounting language which ensures relevance, completeness, understandability, reliability, timeliness, neutrality, verifiability, consistency, comparability and transparency of financial statements. The International Accounting Standards Board (IASB) introduced International Financial Reporting Standards (IFRS). The growing acceptance of IFRSs across the world presents an important challenge and represents a fundamental change in financial reporting. This study contributes to the latest discussions on international financial reporting by reviewing corporate financial statements of Fortune 500 companies to determine how corporations are reporting comprehensive income. We find that companies across the sample are consistent in reporting OCI - they utilize a separate statement for OCI reporting.
\end{abstract}

Keywords: comprehensive income, IFRS, GAAP, financial reporting

DOI: http://dx.doi.org/10.15549/jeecar.v1i2.59

\section{INTRODUCTION}

With the growing globalization of financial markets in the last three decades, including the cross-listing of foreign companies on stock exchanges in other countries throughout the world, there have been numerous calls for mandatory adoption of a single global accounting language which ensures relevance, completeness, understandability, reliability, timeliness, neutrality, verifiability, consistency, comparability and transparency of financial statements. Historically, countries have followed different accounting standards. If different accounting standards are used, however, it's difficult for investors or lenders to compare two companies or determine their financial condition. Publicly traded U.S. firms must prepare financial statements in accordance with the U.S. Financial Accounting Standards Board (FASB) standards, which are known as Generally Accepted Accounting Principles (GAAP). Foreign firms trading in the U.S. are allowed to follow International Financial Reporting Standards (IFRS) developed by the International Accounting Standards Board (IASB). Firms based in the European Union (EU) also use IFRS in the preparation of financial statements.

The IASB significantly reshaped companies' financial reporting by introducing IFRS, which represent a fundamental change in financial reporting (Dholakia, 2013) worldwide. IFRS are a set of principles published by the IASB in order to establish a financial reporting discipline and uniform accounting principles worldwide. The main goal behind the development of IFRS is to enable companies to report their financial information in the most correct, reliable and transparent manner. Supporters of IFRS argue that their use increases the quality of financial reporting, enhances the comparability of financial statement, and hence benefits companies, investors, credit institutions, and auditors (Daske et al., 2008). There are over 150 countries around the world that require the use of IFRS to complete financial statements (http://www.accountingtoday.com/news/IFRS-

Convergence-Adoption); more than 40 percent of the Fortune Global 500 companies now use IFRS. This rising adoption of IFRS is driven by the capital market harmonized accounting standards not only allow market participants to better understand financial situation of a company, it also opens the door for new global opportunities.

Iatridis (2010) states that adoption of IFRS contributes to increasing the quality of accounting information, lessening information asymmetry between shareholders and managers, and reducing cost of capital. Tendeloo and Vanstraelen (2005) point out that one of the main benefits of the mandatory adoption of IFRSs is reduction of information asymmetry and operating cost associated with multiple capital market reporting requirements. In addition, Strubarova (2010) finds that the adoption of IFRS leads to changes in information technology and accounting information systems. Together with the change in financial reporting come changes in financial management. As a result, financial managers are able to make more accurate forecasts and improve budgeting and long-term planning.

The growing acceptance of IFRS across the world presents an important challenge and represents a fundamental change in financial reporting. The accounting standards issued by the FASB and IASB are both similar and different. The similarities remain in the basic principles of accounting (e.g., use of historical cost; property, plant, equipment and lease valuation). However, FASB and GAAP prefer to use a full value approach to determine the value of certain financial instruments while IFRS use a 
mixed method (Johnson, 2010). Differences can also be found in the measurement of interpretations (Aghimie et al., 2013). Furthermore, IFRS are broader and more principal based compared to GAAP. The FASB takes into consideration market regulatory and legal compliances. Many of these differences are embedded in the implementation and enforcement of IFRS standards (Fosbre et al., 2009). Currently, the United States is the only major economic power in the world that has only a tentative mandatory IFRS adoption deadline for publicly traded companies - 2015. There appears to be an overall uneasiness towards the quality of IFRS in the United States (Aghimie et al., 2013). Many companies are not seriously committed to IFRS until the announcement of a firm and mandatory adoption date. Nevertheless, the number of the United States companies voluntarily adopting IFRS is growing (http://www.iasplus.com).

The goal of the study herein is to determine corporate choice regarding the reporting of comprehensive income. Until recently, GAAP allowed firms to report comprehensive income in either an income statement or the statement of equity. Firms report the exact information either way. In perfectly efficient markets, choice of reporting location should not matter to rational investors who fully process information regardless of its reporting location. Nevertheless, most firms chose to report comprehensive income in the statement of equity (Bamber et al., 2010; Bhamornsiri \& Wiggins, 2001; Pandit et al., 2006). Policymakers' preference, though, is that companies report comprehensive income in an income statement, which they consider as more transparent compared to the statement of equity (Bamber et al. 2010). GAAP reporting of comprehensive income was recently aligned with IFRS. Therefore, domestic corporations now have two choices for reporting comprehensive income: in a separate statement of comprehensive income or as a continuation of their current income statement. This study contributes to the latest discussions on financial reporting by reviewing corporate financial statements to determine how comprehensive income is currently being reported. The rest of the paper is organized as follows: overview of previous empirical findings; data, methodology, and discussion of results; conclusion.

\section{LITERATURE REVIEW}

IFRS are becoming the norm. European countries members of the European Union - were required to adopt IFRS by 2005 (Dholakia, 2013). In Australia, the Financial Reporting Council (FRC), which oversees the Australian Accounting Standards Board (AASB) and provides it with the guidance and strategic direction, made the decision to adopt IFRS on January 1, 2005. New Zealand followed suit, requiring financial reporting entities to follow IFRS effective January 1, 2007. Since January 1, 2013, financial statements prepared in conformity with Taiwan-IFRS are required of Taiwanese companies and insurance intermediaries (Aghimien et al., 2013). Companies in Mexico were scheduled to execute IFRS conversion in early 2012. An increasing number of countries in emerging markets adopt IFRS (http://www.iasplus.com).
Presently, the United States is the only major economic power in the world that has not officially set a specific date for IFRS convergence or outright adoption. Aghimien et al. (2013) state that there seems to be an overall apprehension towards the quality of IFRS in the United States. Rapp and Zell (2009) discuss the objection to IFRS adoption. There is a belief that the "principal-based" idea of IFRS leads to much individual discretion in the financial reporting (Derstine \& Bremser, 2010). In the United States, companies have more specific rules they have to abide by when reporting (Lin \& Fink, 2013).

As previously noted, IFRS and GAAP have many similarities. However, standard interpretation leads to a number of differences and is the most debated area of the standards convergence (Aghimien et al., 2013). For example, when it comes to financial statement presentation, GAAP requires current assets and liabilities to be presented before noncurrent assets and liabilities on the balance sheet. There is no prescribed format for IFRS, but often companies report noncurrent items first (Lin \& Fink, 2013). IFRS prohibit reporting extraordinary items on the income statement, while U.S. GAAP allows extraordinary items as long as they are unusual in nature and infrequent in occurrence. Under U.S. GAAP, interest payments are designated as operating cash flows; conversely under IFRS interest payments can be classified as either financing or operating cash flows and a majority of companies generally designated interest payments as financing cash flows. With such differences come many connecting inconsistencies such as the use of Last-In First-Out (LIFO) inventory accounting method. LIFO is permitted under U.S. GAAP, but not under IFRS. U.S companies primarily use LIFO to minimize their tax liability. Under IFRS, LIFO would not be allowed and the companies' tax liability will grow.

Another major difference between IFRS and GAAP is the variation in revenue recognition; GAAP has many industry specific guidelines leading to many exceptions to the basic revenue recognition rules. On the other hand, IFRS is much more relaxed when it comes to revenue recognition. After revenue recognition, other notable differences in reporting include loan accounting, financial instruments disclosure, hedge accounting, and employee benefits (Ernst \& Young, 2009). When it comes to the statement of comprehensive income, IFRS allows a company to either report other comprehensive income (OCI) in a single statement of comprehensive income or in a separate income statement followed by a statement of comprehensive income. On the other hand, U.S. GAAP accepts both reporting methods, but it used to also allow until recently OCI to be presented in the statement of stakeholders' equity. These differences may adversely affect companies, shareholders, investors, and other market participants because of the fact that users of financial statements may not be proficient enough to interpret IFRS adjustments.

\section{DATA, METHODOLOGY, AND DISCUSSION OF RESULTS}

The purpose of this study is to determine how corporations are choosing to report comprehensive income. 
Comprehensive income represents an aggregate approach to income determination. It disaggregates income into separate components and allows "to the extent that it will enhance usefulness in predicting the entities future cash flows" (IASB 2008, para. 3.42). According to Goncharov and Hodgson (2011), comprehensive income reporting should capture all sources of firm's value creation and force managers to consider external factors that affect firm value. A plethora of previous research examines the incremental information content of comprehensive income compared to traditional net income figures. Dhaliwal et al. (1999), Biddle and Choi (2006), Kubota et al. (2006), and Kanagaretnam et al. (2009) link aggregate comprehensive income reporting with higher stock returns. Gordon and Niles (2005) demonstrate that comprehensive income, unlike net income, is relatively stable and difficult to manipulate. Reese and Shane (2012) reveal that OCI items are incrementally value -relevant. This finding supports including OCI in a performance statement with separate presentation.

At the same time, Cheng et al. (1993), O’Hanlon and Pope (1999), Cahan et al. (2000), Isidro et al. (2006), and Goncharov and Hodgson (2011) report no incremental information content for separate comprehensive income components. Lee et al.'s (2006) investigation of the reporting decisions of 82 publicly traded property-liability insurers demonstrates that insurers' comprehensive income reporting choices reflect their tendency toward "cherry picking” as well as their preference in disclosure quality. More recently, Jordan and Clark (2014) find that firm's operating performance affects the reporting preference for comprehensive income. More profitable companies exhibit a lower tendency than less profitable ones to report comprehensive income in a continuous income statement.

As previously noted, U.S. GAAP regarding comprehensive income was recently aligned with IFRS. Domestic corporations now have two choices for reporting comprehensive income: in a separate statement of comprehensive income or as a continuation of their current income statement. Data was collected through a review of the financial statements of Fortune 500 companies for 2013. The most current financial statements were located either on the corporate website or through SEC filings of Form 10-K.

Based on a review of the financial statements of five hundred domestic corporations, 442 corporations (88.4\%) utilize a separate statement for reporting comprehensive income. Thirty-six corporations (7.2\%) report comprehensive income on the income statement. We could not identify the method of choice for the remaining 22 corporations $(4.4 \%)$ for a number of reasons such as no comprehensive income reported. In order to determine whether U.S. corporations align with foreign corporations in their reporting choices, one hundred of the Global Fortune 500 corporations were reviewed. The sample chosen represents the first 100 non-U.S. firms on the list for which the financial statements could be reviewed. Table 1 presents the findings. Countries with five or more companies are presented separately. For ease of comparison, U.S. findings are also presented.

A majority of the foreign companies reviewed chose to present comprehensive income in a separate statement. Although the percentage of companies choosing a separate statement is lower than the U.S. percentage, if China is removed from the equation, the numbers change to: $77.9 \%$ separate statement, $9.3 \%$ income statement, and $12.7 \%$ other. China is certainly the anomaly with the majority of corporations choosing to present comprehensive income as part of the income statement.

Although the percentage of companies choosing a separate statement is lower than the U.S. percentage, if China is removed from the equation, the numbers change to: $77.9 \%$ separate statement, 9.3\% income statement, and $12.7 \%$ other. China is certainly the anomaly with the majority of corporations choosing to present comprehensive income as part of the income statement.

Table 1: Presentation of OCI

\begin{tabular}{|c|c|c|c|c|c|c|}
\hline \multicolumn{7}{|c|}{ Presentation of OCI by Country } \\
\hline \multirow[b]{2}{*}{ Country } & \multicolumn{2}{|c|}{ Separate Statement } & \multicolumn{2}{|c|}{ Income Statement } & \multicolumn{2}{|c|}{$\begin{array}{c}\text { Other (no OCI, shown } \\
\text { in equity) }\end{array}$} \\
\hline & $\mathbf{n}$ & $\%$ & $\mathbf{n}$ & $\%$ & $\mathbf{n}$ & $\%$ \\
\hline U.S. & 442 & 88.4 & 36 & 7.2 & 22 & 4.4 \\
\hline \multicolumn{7}{|l|}{ Foreign co: } \\
\hline China & 4 & 33.3 & 8 & 66.7 & & \\
\hline France & 8 & 80.0 & & & 2 & 20.0 \\
\hline Germany & 12 & 92.8 & & & 1 & 7.2 \\
\hline Italy & 5 & 100.0 & & & & \\
\hline Japan & 12 & 66.7 & 3 & 16.6 & 3 & 16.7 \\
\hline UK & 7 & 100.0 & & & & \\
\hline Other * & 23 & 63.6 & 7 & 21.2 & 5 & 15.2 \\
\hline Total $(n=100)$ & 71 & 71.0 & 18 & 18.0 & 11 & 11.0 \\
\hline
\end{tabular}

As previously noted, the goal of this study was to determine the method of choice for the presentation of comprehensive income. Domestic corporations were found to prefer a separate statement for reporting CI as 
expected, and the majority of foreign corporations also preferred a separate statement. Chinese corporations are the only group in which a majority chose to report CI as part of the income statement. However, a review of Chinese reporting requirements shows that PCR GAAP prefers that all elements of income and comprehensive income be included on the income statement (KPMG, 2011). So, while future studies might try to determine why corporations choose one presentation method over another, it is unclear whether or not the information provided would be beneficial given the number of corporations which choose to present CI within a separate statement.

The reporting of comprehensive income (CI) has become increasingly important over the last several decades. While educated financial statement users are usually familiar with the basic measurement of net income, not everyone is as knowledgeable regarding CI. Prior to 1997, U.S. GAAP did even require the separate reporting of CI. As a review, CI typically includes four elements: holding gain/losses with respect to debt and equity securities; gains/losses with respect to cash flow hedges and net investment in foreign operations; gains/losses or adjustments to pension or post-retirement benefits; and, gains/losses or adjustment with respect to foreign currency translation and intra-entity foreign currency transactions. These adjustments by-passed the income statement and while they affected equity, they were not separately reported. In 1997, SFAS 130 was passed requiring the separate, thus more transparent, reporting of both current CI and accumulated CI.

Some argued that the elements of comprehensive income were already being reported within the financial statements and that separate reporting would have no effect on market value. Dehning and Ratliff's (2004) study looks at firm value immediately before and after the implementation of SFAS 130 and finds no difference in firm value. They conclude that the method of CI disclosure has no effect and is unnecessary. However, in a 2006 study, Chambers, et al., find that separately reporting CI has a positive impact on market value (Chamber et al., 2006). More recent articles point to the fall of major corporations who used OCI as a "dumping ground" for items that they did not want to place on the income statement. While U.S. GAAP and IFRS are aligned regarding the reporting of CI, Hans Hoogervorst, IASB Chairman, noted that the requirements as to what qualifies as CI need to be tightened up so that investors are not misled (Chasan, 2014).

\section{CONCLUSION}

For many years, based on U.S. GAAP, OCI flowed directly to equity and was not necessarily separately identified. In the late 1990s, GAAP changed, requiring companies to report OCI and changes to it. Corporations could choose to report changes to OCI in a separate statement, on their current income statements or within a statement of stockholder's equity. Bottom-line net income has long been an important figure in the financial world and most corporations chose to report OCI as part as the statement of stockholder's equity. The new requirements removed that option. As a result, most corporations have chosen to report OCI on a separate statement of comprehensive income. Although corporations were not surveyed as to why they made this choice, an obvious reason is so as to not confuse the users of financial statement information who may not have knowledge of all the nuances of GAAP. Net income has been focal point for users for many years. To add comprehensive income to the bottom of the income statement may confuse the casual users of financial statement information. Information regarding the method of presentation for OCI is important for several reasons. GAAP and IFRS, as well as the choices made by corporations, seem to be aligned in this area. Furthermore, it also provides useful information for accounting instructors and textbook publishers for discussions regarding OCI.

\section{REFERENCES}

Aghimien, P., \& Bashnini, K. (2013). The development of International Financial Reporting Standards: Origination to present day. International Journal of Business, Accounting, and Finance, 7(2), 1-14.

Bamber L., J. Jiang, K. Petroni, \& Wang, I. (2010). Comprehensive Income: Who's afraid of performance reporting? The Accounting Review, 85(1), 97-126.

Bhamornsiri, S., \& Wiggins, C. (2001). Comprehensive income disclosures. The CPA Journal, October, 4-56.

Biddle, G.C., \& Choi, J.H. (2006). Is comprehensive income useful? Journal of Contemporary Accounting and Economics, 2(1), 1-32.

Cahan, S.F., Courtenay, S.M., Gronewoller, P.L., \& Upton, R. (2000). Value relevance of mandated comprehensive income disclosure. Journal of Business Finance and Accounting, 27(9-10), 1273-1300.

Chambers, D., Linsmeier, T., Shakespeare, C., Sougiannis, T. (2006). An Evaluation of SFAS No. 130 Comprehensive Income Disclosures. Social Science Research Network, http://papers.ssrn.com/sol3/papers.cfm?abstract_id=646 622.

Chasan E. (2014) Accounting 'Dumping Ground' Headed For Clean Up. The Wall Street Journal. February 14, 2014. http://blogs.wsj.com/cfo/2014/02/13/accountingdumping-ground-headed-for-clean-up/.

Cheng, C.S.A., Cheung, J.K., \& Gopalakrishnan, V. (1993). On the usefulness of operating income, net income and comprehensive income in explaining security returns. Accounting and Business Research, 23(91), 195-203.

Daske, H., Hail, L., Leuz, C., \& Verdi, R. (2008). Mandatory IFRS reporting around the world: Early evidence on the economic consequences. Journal of Accounting Research, 46(5), 1085-1142.

Dehning, B., \& Ratliff, P. ( 2004). Comprehensive income: Evidence on the effectiveness of FAS 130. The Journal of American Academy of Business, March, 228-232.

Derstine, R.P., \& Bremster, W.G. (2010). The journey towards IFRS in the United States. CPA Journal, 80(7), 6-9.

Dhaliwal, D., Subramanyam, K.R., \& Trezevant, R. (1999). Is comprehensive income superior to net income as a 
measure of firm performance? Journal of Accounting and Economics, 26(1-3), 43-67.

Dholakia, P. (2013). A perceptual study of the implementation of International Financial Reporting standards for enhancing accounting financial transparency. The IUP Journal of Accounting Research and Audit Practices, 12(1), 63-79.

Ernst \& Young (2009). Converting to IFRS: Effects on US banking and capital markets institutions. New York: EYGM Limited.

Fosbre, A.B., Fosbre, P.B., \& Kraft, E.M. (2009). The globalization of accounting standards: IFRS versus US GAAP. Global Journal of Business Research, 3(1), 6171.

Goncharov, I., \& Hodgson, A. (2011). Measuring and reporting income in Europe. Journal of International Accounting Research, 10(1), 27-59.

Grodon, T., \& Niles, M. (2005). Lucent loses its luster: Accounting for investments rurned bad, Issues in Accounting Education, 20(2), 183-193.

Iatridis, G. (2010). IFRS adoption and financial statement effect: The UK case. International Research Journal of Finance and Economics, 38, 165-172.

International Accounting Standards Board (IASB). (2008). Preliminary Views on Financial Statement Presentation. London, U.K.: IASB.

Isidro H., O’Hanlon, J.F., \& Young, S. (2004). Dirty surplus accounting flows: International evidence. Accounting and Business Research, 34(4), 383-410.

Johnson, A.M. (2010). The IFRS theme park: an alternative approach. CPA Journal, 80(12), 54-59.

Jordan, C. E., \& Clark, S.J. (2014). Reporting preferences under the comprehensive income standard: Examining its use in practice, The CPA Journal, May, 34-42.

Kanagaretnam, K., Mathieu, R., \& Shehata, M. (2009). Usefulness of comprehensive income reporting in Canada, Journal of Accounting Public Policy, 28, 349365.

KPMG (2011). An Overview of New PRC GAAP: Differences between old and new PRC GAAP and its convergence with IFRS. 2nd edition, September 2011.

Kubota, K., Suda, K., \& Takehara, H. (2006). Reporting of the net income plus other comprehensive income: Information content test of the Japanese firms. (Working paper). Musashi University: Tokyo.

Lee Y.J., Petroni,K., \& Shen, M. (2006). Cherry picking, disclosure quality, and comprehensive income reporting choices: The case of Property-Liability Insurers, Contemporary Accounting Research, 23(3), 655-692.

Lin, J., \& Fink, P. (2013). International financial reporting standards: Are they right for the United States? The Journal of Global Business Issues, 7(2), 59-67.

O’Hanlon, J.F., \& Pope, P.F. (1999). The value-relevance of U.K. dirty surplus accounting flows. The British Accounting Review, 31(4), 459-482.

Pandit, G.,Rubenfield, A., \& Phillips, J. (2006). Current NASDAQ corporation methods of reporting comprehensive income. American Journal of Business 21(1), 13-19.

Rapp, R., \& Zell, E. (2009). On the road to IFRS in the United States. Banking and Financial Services Policy Report, 28(2), 1-6.

Rees, L., \& Shane, P. (2012). Academic research and standard-setting: The case of other comprehensive income, Accounting Horizons, 26(4), 789-815.

Strubarova, K. (2010). Shift from national reporting to reporting in accordance with IFRS for small and medium-size entities and its effect on financial management - the case of Czech Republic. Journal of Competitiveness, 2, 74-85.

Tendeloo, B., \& Vanstraelen, A. (2005). Earning management under German GAAP versus IFRS. European Accounting Review, 14(1), 155-180.

U.S. GAAP Accounting Standards (June, 2014). Codification Topic 220: Comprehensive Income. Retrieved from http://accountinginfo.com/financialaccounting-standards/asc-200/220-comprehensiveincome.htm

\section{ABOUT THE AUTHORS}

Kendra Huff, email: Kendra.Huff@tamuk.edu

Dr. Kenda Huff is an assistant professor of accounting at Texas A\&M University - Kingsville. She received her Ph.D. in International Business from UT - Pan American in Edinburg. Her current research interest is in the area of international accounting and International Financial Reporting Standards.

Natalya (Natasha) Delcoure, email: Natalya.Delcoure@tamuk.edu

Dr. Natalya (Natasha) Delcoure is a professor of finance at Texas A\&M University - Kingsville. She received her DBA in Finance from LA Tech, Ruston, LA. Her current research interest is in corporate finance, financial reporting and portfolio diversification. 